\title{
Location of genes in Apis mellifera scutellata-derived mitochondrial DNA of Africanized honey bees
}

\author{
MC Arias 1 , FG Nobrega 2* \\ 1 Universidade de São Paulo, Faculdade de Medicina de Ribeirão Preto, \\ Departamento de Genética, 14049 Ribeirão Preto, São Paulo; \\ 2 Universidade de São Paulo, Instituto de Biociências, Departamento de Biologia, \\ Caixa Postal 11461, 05499 São Paulo, SP, Brazil
}

(Received 21 August 1988; accepted 25 November 1991)

\begin{abstract}
Summary - The mitochondrial DNA of Africanized honey bees having a mIDNA haplotype known from the African subspecies Apis mellifera scutellata, was analysed for the location of 6 mitochondrial genes by hybridization to mitochondrial gene probes from Saccharomyces cerevisiae. Genes for the small and large ribosomal RNAs, cytochrome oxidase subunits I, II and III and apocytochrome $b$ were positioned relative to the mitochondrial DNA fragments generated with 6 different restriction endonucleases utilized singly or in combination. Results show that these genes are in the same relative positions as Drosophila genes.
\end{abstract}

Africanized honey bee / mitochondrial gene / gene mapping / restriction endonuclease / molecular hybridization

\section{INTRODUCTION}

Mitochondrial DNA (mtDNA) has recently been the focus of a number of molecular, genetic and evolutionary studies (Wilson et al, 1985; Tzagoloff and Myers, 1986; Avise et al, 1987; Moritz et al, 1987). In multicellular animals, mtDNA is a circular molecule of approximately $16 \mathrm{~kb}$ carrying a set of highly conserved genes throughout the species and phyla studied so far
(Wilson et al, 1985). The complete determination of nucleotide sequences of mtDNA in man (Anderson et al, 1981), mice (Bibb et al, 1981), cattle (Anderson et al, 1982), Xenopus (Roe et al, 1985) and Drosophila yakuba (Clary and Wolstenholme, 1984) revealed genes for 2 ribosomal RNAs, 22 tRNAs, 3 subunits of cytochrome oxidase, 2 subunits of ATPase, apocytochrome $b$ and 7 coding regions for different subunits of the NADH dehydrogenase (Mariottini et al, 1986).

* Correspondence and reprints

Abbreviations: mitochondrial gene abbreviations are explained in the legend to figure 3 . 
These studies showed conservation of gene content but revealed a distinct gene order among phyla and different IRNA positions (Clary and Wolstenholme, 1985; Dubin et al, 1986). Partial sequencing work in honey bee mtDNA has been completed by Crozier et al (1989), encompassing the $\mathrm{CO}$ and COll genes. Here we report on the location of 6 mitochondrial genes in the honey bee determined by heterologous hybridization with mtDNA gene probes from Saccharomyces cerevisiae.

\section{MATERIALS AND METHODS}

Samples of $\approx 300$ white-eyed pupae, 11 days old, were collected from 2 Africanized colonies kept at the Laboratorio de Abelhas, Depto de Ecologia Geral, USP, Såo Paulo. Mitochondrial DNA was isolated from purified organelles according to the procedure of Moritz et al (1986).

Restriction enzyme digestion, agarose gel electrophoresis, Southern transfer of DNA fragments to Hybond-N filters (Amersham), preparation of nick-translated radioactive DNA probes and hybridization conditions were as described in Sambrook et al (1989). Mitochondrial DNA from yeast petite mutants was prepared as described by Nobrega and Nobrega (1986). The yeast petite strains used are described in table 1 .

Hybridization with heterologous yeast probes was performed overnight in $6 \times$ SSC, $0.1 \%$ Sar- osyl, $50 \mu \mathrm{g} / \mathrm{ml}$ denatured carrier DNA at $40^{\circ} \mathrm{C}$. The filters were initially washed in $2 \times$ SSC, $0.1 \%$ Sarkosyl at room temperature prior to autoradiography. After the first exposure the filters were washed in more stringent conditions by incubation in the wash solution for $1 \mathrm{~h}$ at 45,50 , 55 or $60^{\circ} \mathrm{C}$ with autoradiography after each wash to determine the location of the DNA bands most homologous to the probe utilized.

Rehybridization of filters to new probes was carried out after removal of the radioactive probe by incubation at $45^{\circ} \mathrm{C}$ for $15 \mathrm{~min}$ in $0.4 \mathrm{~N}$ $\mathrm{NaOH}$ followed by washes in $2 \times \mathrm{SSC}$. The filters were exposed to X-ray film to ensure complete removal of label before re-use.

\section{RESULTS AND DISCUSSION}

Single and double digestions used for hybridization studies are shown in figure 1 and table II and results of a typical hybridization experiment are shown in figure 2 . Hybridizations clearly indicated gene position except for the COIII gene. In this case '(fig 2, lanes 9 and 10), there is a strong labeling of the second EcoRI mtDNA band ( $3950 \mathrm{bp}$ ) but there is always a weaker labeling of the first ( $9400 \mathrm{bp}$ ) and third ( $3200 \mathrm{bp}$ ) band as well. This result was not improved with the increased stringency. We decided to place COIII at the first EcoRI fragment (9 $400 \mathrm{bp}$ ) due to results of double digest with EcoRI and Clal that

Table I. Saccharomyces cerevisiae petite mutants utilized as probes.

\begin{tabular}{llll}
\hline Petite & Gene & $\begin{array}{c}\text { Size of mtDNA } \\
\text { repeating unit } \\
(\mathrm{kbp})\end{array}$ & References \\
& & & \\
& & 7,6 & Nobrega and Tzagoloff (1980) \\
DS400/A12 & Apocytochrome $b$ & 3,7 & Bonitz et al (1980) \\
DS6/407 & Cytochrome oxidase subunit I & 4,5 & Coruzzi and Tzagoloff (1979) \\
DS200/A1 & Cytochrome oxidase subunit $/ I$ & 4,1 & Thalenfeld and Tzagoloff (1980) \\
DS40 & Cytochrome oxidase subunit III & 2,6 & Li and Tzagoloff (1982) \\
DS80 & Small ribosomal RNA & 3,5 & Dujon (1980) \\
DS631 & Large ribosomal RNA & & \\
\hline
\end{tabular}




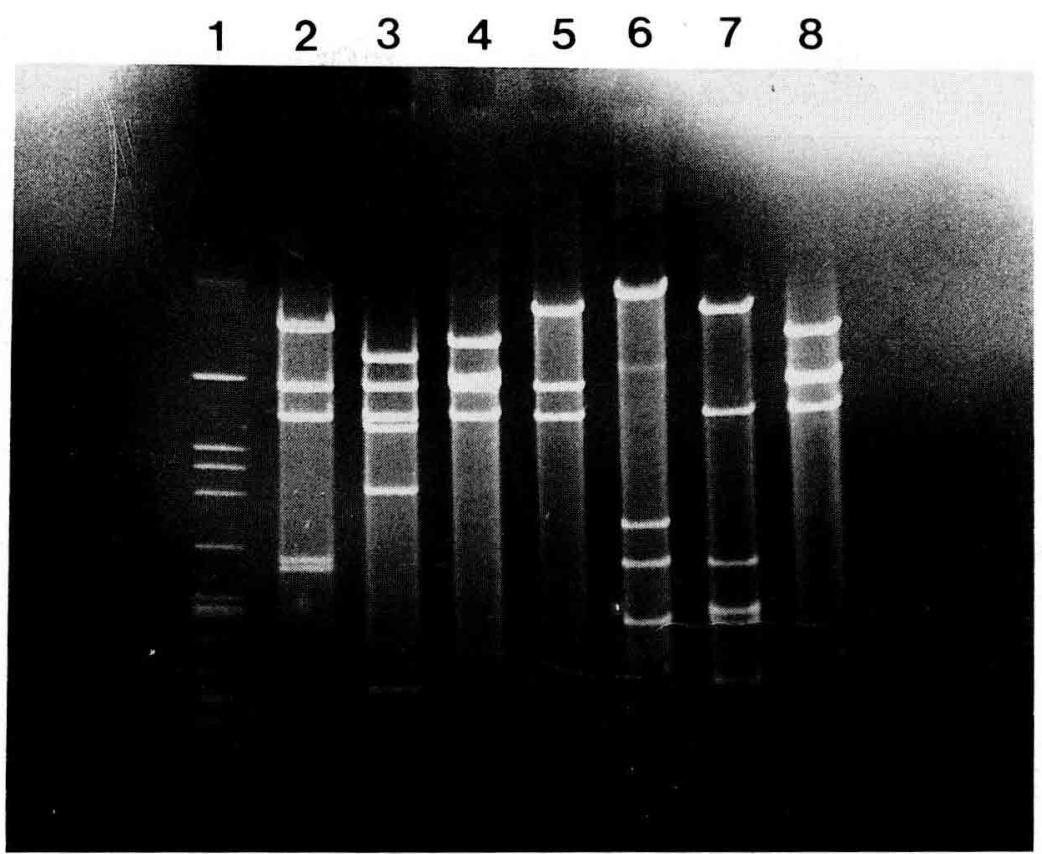

Fig 1. Ethidium bromide stained mitrochondrial DNA of Apis mellifera scutellata digested with different restriction enzymes and electrophoresed in $0.9 \%$ agarose gels. 1 , lambda DNA digested with Haelll (the 6 larger DNA fragments are $4.1 ; 2.4 ; 2.1 ; 1.8 ; 1.3$ and $1.0 \mathrm{~kb}$ long respectively); 2, HindlII/ EcoRI; 3, Accl/EcoRl; 4, EcoRV/EcoRI; 5, EcoRI; 6, Clal; 7, Clal/EcoRl; and 8, Xhol/EcoRI.

split the second EcoRI fragment ( $3950 \mathrm{bp}$ ) (Arias et al, 1990). Autoradiography of this digest after hybridization with COlll probe showed strong signal at the first EcoRl fragment (9 $400 \mathrm{bp}$ ), no labeling of Clal pieces and a weak signal at the third Eco $\mathrm{RI}$ fragment (3200 bp) band. A mitochondrial gene map based on hybridization with yeast probes appears in figure 3 .

The introduction of African bees (Apis mellifera scutellata) to Brazil in 1956 followed by dispersal of descendents throughout South and Central America stimulated investigators to look for molecu- lar markers to study the process of Africanization. Restriction fragment polymorphism in honey bee mtDNA has been widely used to provide molecular markers for such studies (Moritz et al, 1986; Smith, 1988; Smith et al, 1989; Hall and Muralidharan, 1989; Smith and Brown, 1990; Sheppard et al, 1991).

The size of mtDNA in Apis mellifera has been estimated at around $16 \mathrm{~kb}$ long (Smith, 1988; Arias et al, 1990) and is similar in size to that reported for Drosophila yakuba (Clary and Wolstenholme, 1984) and man (Cann et al, 1987). Major gene 
rable II. Apis mellifera mtDNA fragment sizes after restriction endonuclease digestion.

\begin{tabular}{|c|c|c|c|c|c|c|c|c|}
\hline Enzymes & $\begin{array}{l}\text { HindIII/a } \\
\text { Eco } R I\end{array}$ & $\begin{array}{l}\mathrm{Acc} / \mathrm{a} \\
\mathrm{Eco} R I\end{array}$ & $\begin{array}{l}\text { EcoRVa } \\
\text { EcoRI }\end{array}$ & EcoRI & Clal & $\begin{array}{l}\text { Clala } \\
\text { EcoRI }\end{array}$ & $\begin{array}{l}\text { Xhola } \\
\text { EcoRl }\end{array}$ & $\begin{array}{l}\text { Acc/a } \\
\text { HindIII }\end{array}$ \\
\hline \multirow[t]{2}{*}{ Fragment } & 7000 & 4530 & 5300 & 9400 & 13000 & 9400 & 5450 & 11000 \\
\hline & 3950 & 3950 & 4100 & 3950 & 1480 & 3200 & 3950 & 4400 \\
\hline \multirow[t]{2}{*}{ Sizes } & 3200 & 3200 & 3950 & 3200 & 1200 & 1200 & 3950 & 700 \\
\hline & 1230 & 2850 & 3200 & & 800 & 900 & 3200 & 500 \\
\hline \multirow[t]{2}{*}{ (bp) } & 1170 & 1720 & & & & 900 & & 500 \\
\hline & & 500 & & & & $\begin{array}{l}800 \\
500\end{array}$ & & \\
\hline Total & 16550 & 16750 & 16550 & 16550 & 16480 & 16900 & 16550 & 17100 \\
\hline
\end{tabular}

a Double digestion.

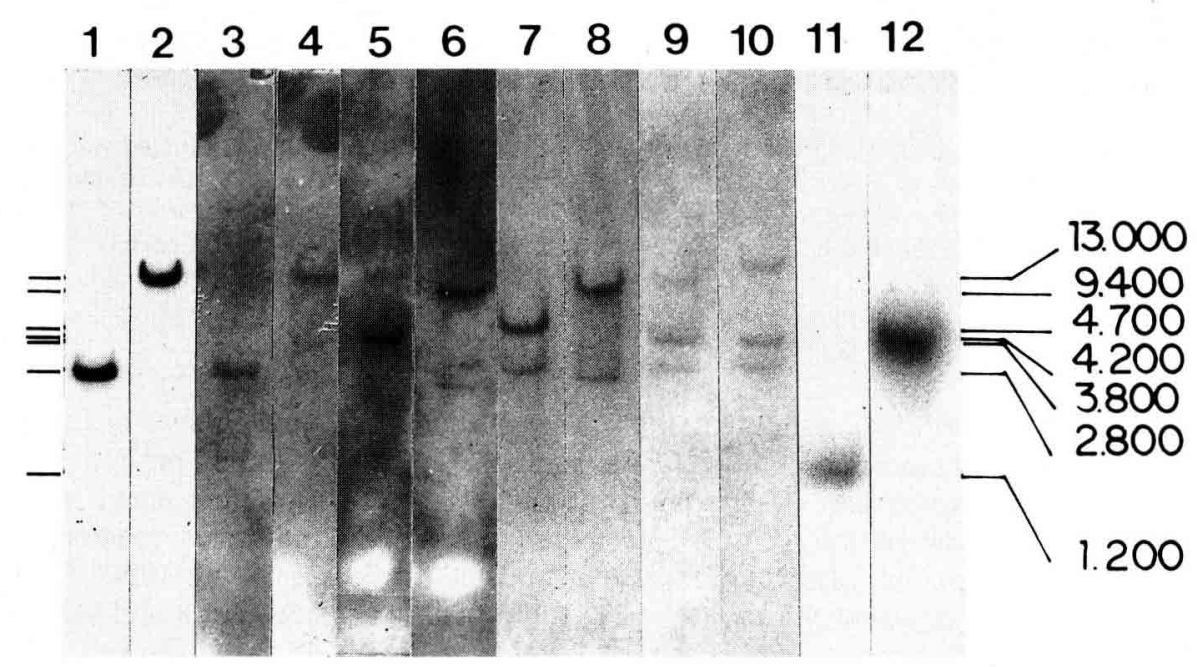

Fig 2. Composed autoradiographs of representative hybridization experiments of yeast mitrochondrial gene probes to Apis mellifera scutellata mtDNA restriction fragments. Digestion was carried out with EcoRI (lanes 1, 3, 6, 8, 10, 12); Clal (lanes 2 and 4); Accl/Hindlll (lane 5); EcoRl/HindIII (lane 9); EcoRl/EcoRV (lane 7) and Clal/EcoRI (lane 11). Probes utilized correspond to the following genes: large rRNA (lanes 1 and 2); small rRNA (lanes 3 and 4); cytochrome oxidase subunit I (lanes 5 and 6); cytochrome oxidase subunit II (lanes 7 and 8); cytochrome oxidase subunit III (lanes 9 and 10) and apocytochrome $b$ (lanes 11 and 12). The position and size (base pairs) of the corresponding mtDNA fragments is shown. 


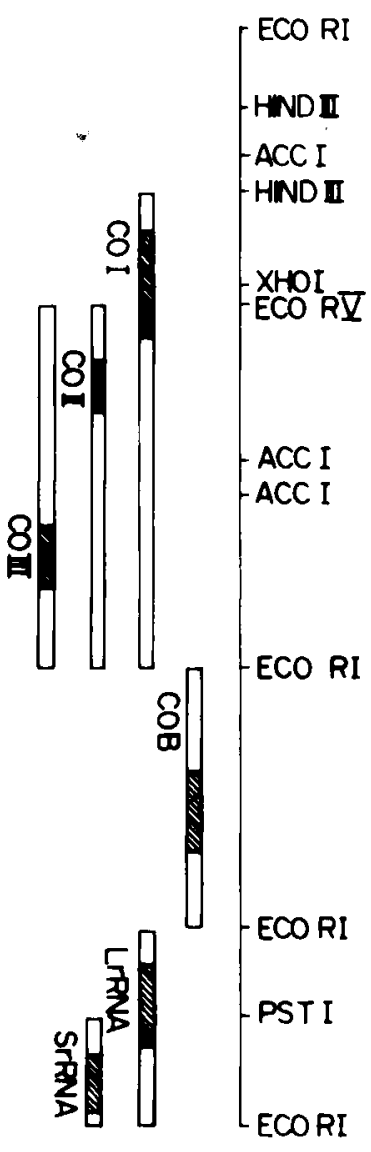

Fig 3. Physical map of mitochondrial genome of presumptive Apis mellifera scutellata. The 16600 bp circular genome has been linearized at the EcoRl site located between the rRNA gene and the $\mathrm{CO}$ gene. The position of hybridizable regions for 6 mitochondrial gene probes is show as open bars. The shaded areas within correspond to the estimated location of the coding region for each gene, assuming that there is no gene overlap and taking into account published data for the large rDNA gene (Vlasak et $a l, 1987)$ and the segment that encompasses the cytochrome oxidase subunits I and II (Crozier et al, 1989). COI, II and III: cytochrome oxidase subunits 1,2 , and 3 respectively; COB: apocytochrome $b$; SrRNA: small ribosomal RNA and LrRNA: large ribosomal RNA. order is identical in Xenopus, Homo, Bos and Mus (Moritz et al, 1987), although inversions and transpositions are frequent, chiefly among tRNA genes (Clary and Wolstenholme, 1985; Wolstenholme et al, 1987). Studies in fishes suggest that there is conservation of major gene order in the phylum Chordata (Moritz et al, 1987).

Sequence data reported to date from honey bee mtDNA describe a set of 6 consecutive genes (tRNAs for Leu, Asp, Lys and Trp, COI, COII) and the large rRNA gene in Apis mellifera ligustica (Crozier et al, 1989 and Vlasak et al, 1987, respectively). Compared to Drosophila, Apis gene order displays translocations of 3 of the 4 tRNA genes. Such tRNA transpositions have been documented between most orders (Dubin et al,1986; Haucke and Gellissen, 1988) but no transposition affecting respiratory complex subunits have been found.

Conditions of reduced stringency were utilized to map, by hybridization to yeast probes, the corresponding honey bee mitochondrial genes. Most hybrids remained intact after washes in $2 \times$ SSC and $60^{\circ} \mathrm{C}$ indicating a considerable degree of similarity. Yeast probes are available for individual mtDNA genes and have been used successfully in mapping organelle genes (Macino, 1980; Spithill et al, 1983; Borkhardt and Olson, 1986). Concerning our difficulty in positioning the COIII gene, it is interesting that Spithill et al (1983) reported extensive hybridization of the yeast COIII probe to several non-adjacent mtDNA fragments in Leishmania tarentolae.

Our results reveal a conserved gene order between Apis mellifera and Drosophila, and reinforce the inversion detected between invertebrate and vertebrate genomes concerning the large and small ribosomal subunit genes (fig 4). 
A

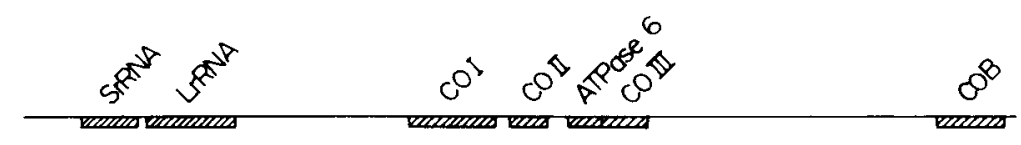

B

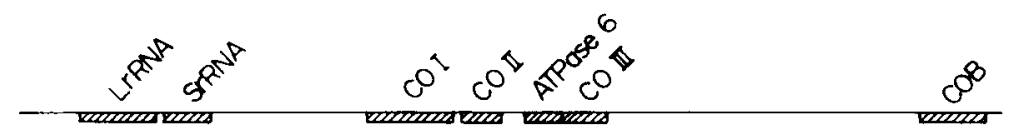

C

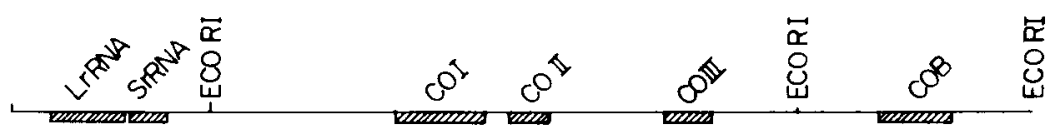

Fig 4. Comparative mitochondrial gene maps. A, mice (Bibb et al, 1981), B, Drosophila yakuba (Clary and Wolstenholme, 1985); and C, Apis mellifera scutellata (present work).

\section{ACKNOWLEDGMENTS}

We thank J Lino and CK Takahashi for technical support, L Gonzaga de Castro for the illustrations and $A$ Tzagoloff for providing the yeast petite mutants. This work was supported by FA. PESP, CNPq, BIOQ/FINEP and the USP/BID project.

Résumé - Localisation des gènes sur l'ADN mitochondrial issu d'Apis mellifera scutellata chez des abeilles africanisées. L'ADN mitochondrial (ADNmt) est une molécule circulaire longue d'environ 16 à $18 \mathrm{~kb}$. La détermination complète des séquences de nucléotides chez l'homme, la pieuvre, la vache et la drosophile a montré que le nombre de gènes et leur organisation sont restés quasiment inchangés au cours de l'évolution, l'ordre ne changeant qu'entre les phyla et principalement parmi les gènes d'ARN ${ }_{\mathrm{t}}$. Nous avons déterminé la position de 6 gènes dans la molécule d'ADN $\mathrm{mt}_{\mathrm{mt}}$ issue d'abeilles présumées africanisées. Les mitochondries provenant d'environ 300 nymphes aux yeux blancs ont été purifiées par centrifugation dans un gradient de saccharose. L'ADN $\mathrm{mt}_{\mathrm{mt}}$ a été extrait et purifié. Les échantillons ont été digérés soit seuls, soit en combinaison avec les endonucléases suivantes : Accl, Clal, EcoRl, EcoRV, Hindll et Xhol (fig 1, tableau II). Les fragments ont été séparés sur des gels d'agarose à $0,9 \%$ et transférés sur des filtres Hybond-N. Des sondes spécifiques pour les principaux gènes mitochondriaux (COI, COIl, COll,, CytB, sous-unité ribosomale petite et grande) (tableau I) ont été obtenues à partir des mutants "petite" de la levure Saccharomyces cerevisae et marqués par nick translation. L'hybridation a été faite en une nuit à $40^{\circ} \mathrm{C}$ dans $6 \times$ SSC, du Sarkosyl à $0,1 \%$ et $50 \mu \mathrm{g} / \mathrm{ml}$ d'ADN porteur dénaturé. Nous avons utilisé une température basse $\left(40^{\circ} \mathrm{C}\right)$ afin d'obtenir la formation d'hybride avec les sondes de levure hétérologues. 
Après autoradiographie, les filtres ont été lavés successivement dans $2 \times$ SSC, Sarkosyl à $0,1 \%$ à $45,50,55$ et $60^{\circ} \mathrm{C}$ avec autoradiographie après chaque lavage pour révéler les bandes ayant la plus grande stabilité d'hybride. La figure 2 donne les résultats. Nous avons construit une carte des gènes pour l'abeille africanisée d'après les résultats de l'hybridation (fig 3). Le gène COIII est placé sur le premier fragment $E c o R I$ bien que la sonde montre une homologie avec les 2 autres fragments EcoRI. La comparaison avec les cartes du génome de la drosophile et de la souris montre qu'entre les 2 insectes, l'ordre des gènes est conservé et que l'on retrouve l'inversion déjà mise en évidence entre les gènes de l'ARN ribosomal des Vertébrés et ceux des Invertébrés.

abeille africanisée / gène mitochondrial / cartographie de gènes / endonucléase de restriction / hybridation moléculaire

\section{Zusammenfassung - Lage von Genen in der von Apis mellifera scutellata ab-} stammenden mitochondrialen DNA afrikanisierter Bienen. Die mitochondriale DNA (mtDNA) ist ein ringförmiges Molekül von etwa 16 bis $18 \mathrm{~kb}$ Länge. Die vollständige Bestimmung der Nukleotid-Sequenz bei Mensch, Xenopus, Rind und Drosophila haben gezeigt, daß Gengehalt und ihre Organisation während der Evolution in hohem Maße unverändert geblieben sind; sie zeigen nur beim Vergleich zwischen Tierstämmen Unterschiede in der Anordnung, und zwar vorwiegend bei Genen der tRNA. Wir bestimmten die Lage von sechs Genen des mitochondrialen DNA-Moleküls der Afrikanisierten Biene, die vermutlich von Apis mellifera scutellata abstammt. Von ungefähr 300 weißäugigen Puppen wurden die Mitochondrien durch Zentrifu- gierung im Sucrosegradienten gereinigt. Die mtDNA wurde aus den Organellen extrahiert und gereinigt. Die Proben wurden für sich oder gemeinsam mit folgenden Endonukleasen abgebaut: Accl, Clal, EcoRi, EcoRV, Hindlll, und Xhol (Abb 1 und Tabelle II). Die Fragmente wurden in $0.9 \%$ Agarosegel getrennt und auf Hybond-N-Filter übertragen. Spezifische Untersuchungen auf die mitochondrialen Hauptgene (COI, COII, COIII, CytB, kleine und große ribosomale Untereinheit; Tab I) wurden mittels geeigneter "petite" Hefemutanten durchgeführt und mit NickTranslation markiert. Die Hybridisierung wurde über Nacht in $6 \times$ SSC, $0.1 \%$ Sarcosyl und $50 \mu \mathrm{g} / \mathrm{ml}$ denaturierter Träger-DNA bei $40^{\circ} \mathrm{C}$ durchgeführt. Wir benutzten niedrigere Temperaturen $\left(40^{\circ} \mathrm{C}\right)$, um Hybridbildungen mit den heterologen Hefesonden zu ermöglichen. Nach der Autoradiographie wurden die Filter sukzessive in $2 x$ SSC, $0.1 \%$ Sarkosyl bei $45,50,55$ und $60^{\circ} \mathrm{C}$ gewaschen, mit Autoradiographie nach jedem Auswaschen; damit sollten die Bande mit der höchsten Hybrid-Stabilität aufgedeckt werden. Die Ergebnisse werden in Abbildung 2 gezeigt. Wir haben nach den Hybridisierungsresultaten eine Genkarte für die afrikanisierte Honigbiene konstruiert (Abb 3). Das COIll-Gen kam auf dem ersten EcoRI-Fragmen zu liegen, obwohl die Sonde eine Homologie mit den anderen beiden EcoRl-Fragmenten zeigte. Diese Karte zeigt bei Vergleich mit den Genkarten von Drosophila und Maus (Abb 4) eine konservative Genanordnung bei den beiden Insekten und deckt dieselbe Inversion auf, die schon früher bei den ribosomalen RNA-Genen zwischen Vertebraten und Invertebraten gefunden wurde.

afrikanisierte Biene / mitochondriales Gen / Genkarte / Endonuklease / molekulare Hybridisierung 


\section{REFERENCES}

Anderson S, Bankier AT, Barrell GT, De Bruijn MHL, Coulson AR, Drouin J, Eperon IC, Nierlich DP, Roe BA, Sanger F, Schreier PH, Smith AJH, Staden R, Young IG (1981) Sequence organization of the human mitochondrial genome. Nature (Lond) 290, 457-465

Anderson S, De Bruijn MHL, Coulson AR, Eperon IC, Sanger F, Young IG (1982) Complete sequence of bovine mitochondrial DNA. Conserved features of the mammalian mitochondrial genome. J Mol Biol 156, 683-717

Arias MC, Soares AEE, Nobrega FG (1990) Improvements to the mitochondrial restriction maps for italian and africanized honey bees. Braz J Genet 13, 501-507

Avise JC, Arnold J, Ball RM, Bermingham E, Lamb T, Niegel JE, Reeb CA, Saunders NC (1987) Intraspecific phylogeography: the mitochondrial DNA bridge between population genetics and systematics. Ann Rev Ecol Syst 18, 489-522

Bibb MJ, Van Etten RA, Wright CT, Walberg MW, Clayton DA (1981) Sequence and organization of mouse mitochondrial DNA. Cell 26, 167-180

Borkhardt B, Olson LW (1986) The mitochondrial genome of the aquatic phycomycete Blastocladiella emersoni. Curr Genet 11,139141

Bonitz SG, Coruzzi G, Thalenfeld BE, Tzagoloff A (1980) Assembly of mitochondrial membrane system. Structure and nucleotide sequence of the gene coding for subunit 1 of yeast cytochrome oxidase. $J$ Biol Chem 255 , 11927-11941

Cann RL, Stoneking M, Wilson AC (1987) Mitochondrial DNA and human evolution. $\mathrm{Na}$ ture (Lond) 325, 31-36

Clary DO, Wolstenholme DR (1984) The Drosophila mitochondrial genome. In: Oxford Surveys on Eukaryotic Genes (Maclean N, ed) Oxford University Press, vol 1, 1-35

Clary DO, Wolstenholme DR (1985) The mitochondrial DNA molecule of Drosophila yakuba: nucleotide sequence, gene organization and genetic code. J Mol Evol 22, 252- 271

Coruzzi G, Tzagoloff A (1979) Assembly of the mitochondrial membrane system. DNA se- quence of subunit II of yeast cytochrome oxidase. J Biol Chem 254, 9324-9330

Crozier RH, Crozier YC, Mackinlay AG (1989) The $\mathrm{CO} /$ and $\mathrm{CO} / /$ region of honeybee mitochondrial DNA: evidence for variation in insect mitochondrial evolutionary rates. Mol Biol Evol 6, 399-411

Dubin DT, HsuChen CC, Tillotson LE (1986) Mosquito mitochondrial transfer RNAs for valine, glycine and glutamate:RNA and gene sequences and vicinal genome organization. Curr Genet 10, 701-707

Dujon B (1980) Sequence of the intron and flanking exons of the mitochondrial $21 S$ rRNA gene of yeast strains having different alleles at the $w$ and rib-1 loci. Cell 20, 185197

Hall HG, Muralidharan K (1989) Evidence from mitochondrial DNA that African honey bees spread as continuous maternal lineages. $\mathrm{Na}$ ture (Lond) 339, 211-213

Haucke HR, Gellissen G (1988) Different mitochondrial gene order among insects: exchanged IRNA gene position in the COIII COIII region between an orthopteran and a dipteran species. Curr Genet 14, 471-476

Li M, Tzagoloff $A$ (1982) Identification of the paramomycin-resistance mutation in the $15 S$ rRNA gene of yeast mitochondria. J Biol Chem 257, 5921-5928

Macino G (1980) Mapping of mitochondrial structural genes in Neurospora crassa. J Biol Chem 255,10523-10565

Mariottini P, Chomyn A, Riley M, Cottrell B, Doolittle RF, Attardi G (1986) Identification of the polypeptides encoded in the unassigned reading frames $2,4,4 \mathrm{~L}$ and 5 of human mitochondrial DNA. Proc Natl Acad Sci USA 83, 1563-1567

Moritz C, Dowling TE, Brown WM (1987) Evolution of animal mitochondrial DNA. Relevance for population biology and systematics. Ann Rev Ecol Syst 18, 269-292

Moritz RFA, Hawkins CF, Crozier RH, Mackinlay AG (1986) A mitochondrial DNA polymorphism in honeybee (Apis mellifera). Experientia 42, 322-324

Nobrega FG, Tzagoloff A (1980) Assembly of the mitochondrial membrane system. DNA sequence and organization of the cyto- 
chrome $b$ gene in Saccharomyces cerevisiae D273-10B. J Biol Chem 255, 9828-9837

Nobrega MP, Nobrega FG (1986) Mapping and sequencing of the wild-type and mutant (G116-40) alleles of the tyrosyl-tRNA mitochondrial gene in Saccharomyces cerevisiae. $J$ Biol Chem 261, 3054-3059

Roe BA, Ma DP, Wilson RK, Wong JHF (1985) The complete nucleotide sequence of the Xenopus laevis mitochondrial genome. J Biol Chem 260, 9759-9774

Sambrook J, Fritsch EF, Maniatis T (1989) Molecular Cloning: A Laboratory Manual. Cold Spring Harbor Laboratory, Cold Spring Harbor, New York

Sheppard WS, Rinderer TE, Mazzoli JA, Stelzer JA and Shimanuki $H$ (1991) Gene flow between African- and European-derived honey bee populations in Argentine. Nature (Lond) 349, 782-784

Smith DR (1988) Mitochondrial DNA polymorphisms in five Old World subspecies of honey bees and New World hybrids. In: Africanized Honey Bees and Bee Mites (Needham GR, Page RE JR, Delfinado-Baker M, Bowman CL, eds) John Wiley and Sons, New York, 303312

Smith DR, Brown WM (1990) Restriction endonuclease cleavage site and length polymorphisms in mitochondrial DNA of Apis mellifera mellifera and $A m$ carnica (Hymenoptera: Apidae). Ann Entomol Soc Am 83, 81-88

Smith DR, Taylor OR, Brown WM (1989) Neotropical Africanized honey bees have African mitochondrial DNA. Nature (Lond) 339, 213215

Spithill TW, Simpson AM, Simpson L (1983) Identification of sequence homologies between maxicircle DNA of $L$ tarentolae and specific yeast mitochondrial structural genes. In: Manipulation and Expression of Genes in Eukaryotes (Nagley P, Linnane AW, Peacock NJ, Pateman JA, eds) Academic Press, New York, 307-311

Thalenfeld BE, Tzagoloff A (1980) Assembly of mitochondrial membrane system. Sequence of the oxi 2 gene of yeast mitochondrial DNA. J Biol Chem 255, 6173-6180

Tzagoloff A, Myers AM (1986) Genetics of mitochondrial biogenesis. Ann Rev Biochem 55, 249-285

Vlasak I, Burgschwaiger S, Kreil G (1987) Nucleotide sequence of the large ribosomal RNA of honeybee mitochondria. Nucleic ACids Res 15, 2388

Wilson AC, Cann RL, George M, Gyllensten UB, Helm-Bychowski KM, Higushi RG, Palumbi SR, Prager EM, Sage RD, Stoneking $M$ (1985) Mitochondrial DNA and two perspectives on evolutionary genetics. Biol J Linn Soc 26, 375-400

Wolstenholme DR, Macfarlane JL, Okimoto R, Clary DO, Wahleitner JA (1987) Bizarre tRNAs inferred from DNA sequences of mitochondrial genomes of nematode worms. Proc Natl Acad Sci USA 84, 1324-1328 